On March 28, 1859-that is 66 years after Hunter's death -his remains were reinterred in the north aisle of Westminster Abbey. A brass tablet in the stone floor of the nave of the Abbey, placed there by the Royal College of Surgeons of England, records the admiration of the College for :

"His genius as a gifted interpreter of the Divine Power and Wisdom at work in the laws of Organic Life, and their grateful veneration for his services to mankind as the Founder of Scientific Surgery."

The statue of John Hunter in the Museum of the College was erected by subscription on the occasion when John Hunter's remains were transferred to Westminster Abbey, in 1859. The statue is the work of Weeks, and is a copy in marble of the celebrated picture of John Hunter by Sir Joshua Reynolds in the Council Room of the College.

On February 14, 1952, Hunter's birthday, a service was held at St. Martin-in-the-Fields to commemorate the fact that John Hunter was buried in the church until 1859, when his remains were removed to Westminster Abbey. The service was conducted by the Dean of Westminster; the lesson read by the President of the Royal College of Surgeons, Sir Cecil Wakeley; and an address given by Sir Gordon Gordon-Taylor. A plaque was set up in the crypt, and was unveiled by Sir Henry Dale, a Hunterian Trustee. The plaque, besides recording the facts of Hunter's interment and reinterment, commemorates the name of Frank Buckland, the discoverer of the Hunter coffin. As Sir Gordon Gordon-Taylor remarked in his address: "It was owing to the zeal and enthusiasm of the late George Grey Turner that the project to place the plaque in the church had come to fruition."

On the front page of a brochure which deals with the restoration and development of the Royal College of Surgeons of England, the following lines appear: "All through the ages a golden truth is blazoned; the path of Progress is by Experiment, Research, and Trial." Surely here is the essence of the Hunterian tradition, of which the Royal College of Surgeons of England is the custodian.

\section{TREATMENT OF PATIENTS WITH MYELOSCLEROSIS}

\section{BY \\ R. A. HICKLING, M.D., F.R.C.P. Physician, Charing Cross Hospital}

Unless new bone formation in the marrow spaces has occurred (osteosclerosis), which can be detected by $x$ ray examination, the presence of fibrosis of the bone marrow can be proved in life only by biopsy of a bone in which red marrow is normally present. Needle puncture of the sternum and other bones is not a reliable method of detecting the presence of fibrosis. Bonemarrow cells are usually present among the fibrous tissue or in spaces lined by endothelium in the fibrous tissue, and the fibrosis may be patchy, and an active portion of bone marrow may be encountered. When the fibrosis is very dense, however, few bone-marrow cells may be present.

The object of this paper is to draw attention to the good results which may be obtained by $x$-ray treatment in certain cases, results comparable to those obtained in treating typical cases of chronic myeloid leukaemia (chronic leukaemic myelosis). Some recent writers, assuming that the enlargement of the spleen is a compensatory process to replace the fibrous bone marrow, have stated that $x$-ray treatment is harmful (Levinson and Limarzi, 1947 ; Paolino, 1949 ; Wyatt and Sommers, 1950).
Rarely patients with myelosclerosis may have the changes in the circulating blood of polycythaemia (Hirsch, 1935 ; Vaughan and Harrison, 1939; Sussman, 1947 ; Marson and Meynell, 1949, 1952) or of myeloid leukaemia (Heuck, 1879; Rosenthal and Erf, 1943; Sussman, 1947), but more commonly the changes are those of anaemia. Rarely the patient may die, within a few months from the first symptoms, of severe anaemia, with haemorrhages into the skin and from mucous membranes, presenting a clinical picture like that of acute or subacute leukaemia (Assmann, 1907; Mozer, 1927; Wood and Andrews, 1949). But most patients with myelosclerosis have splenomegaly, slight or no anaemia, with an increase in circulating leucocytes of varying degree and varying proportions of immature leucocytes and nucleated red cells. The enlargement of the spleen is due to myeloid metaplasia, usually involving granulocytes, nucleated red cells, and megakaryocytes. The megakaryocytes are often the most prominent cells in the myeloid metaplasia, partly because of their size and the ease with which they are recognized ("megakaryocytic myelosis").

When severe anaemia is present blood transfusion is the best treatment, and some patients have been kept alive for many years by repeated transfusions (Collins, Sanger, Allen, and Race, 1950). Some patients, however, do not respond to blood transfusions, and these may die of severe anaemia after a short illness. The anaemia does not respond to iron by mouth, or to liver extract by mouth or by injection. But most patients with myelosclerosis live a long time, and in these spontaneous remissions from anaemia may occur, and even polycythaemia may develop (Windholz and Foster, 1947; Hutt and Richardson, 1950).

The patients with myelosclerosis who have either no anaemia or only slight anaemia usually seek advice because of symptoms due to the large spleen. They may, however, have severe gastro-intestinal haemorrhages and large haemorrhages into the tissues, usually have cramps in the legs at night, and may have attacks of gout. Many of these patients ultimately die of severe anaemia, after a long period, but some never develop anaemia throughout and die of weakness and wasting or heart failure.

It is those patients with a high leucocytosis and a high proportion of immature cells in the circulating blood who respond well to $x$-ray treatment, regardless of the degree of myelosclerosis.

In many of these patients the main trouble is abdominal discomfort due to the large spleen; the general health of the patient may be unaffected, and he may be able to lead an active life consistent with his age. In such cases no treatment should be given except for encouragement to bear with the abdominal symptoms, some relief from which may be given by an abdominal supporting belt. Later on symptoms of general illhealth may occur, such as tiredness, weakness, and, later still, wasting. The first course of $x$-ray treatment produces the best result, and should be postponed until either severe abdominal symptoms or general symptoms of ill-health occur. This may produce a very good result, the abdominal symptoms diminishing or disappearing as the spleen decreases in size-weakness, tiredness, and cramps in the legs disappearing, and the patient being enabled to lead an active life again. This result is accompanied by a decrease in the numbers of the circulating leucocytes and of the immature leucocytes and nucleated red cells, and a decrease in numbers 
of basophils and eosinophils if these were previously abnormally high. The improvement in the patient's condition lasts varying periods of time, as in typical cases of chronic myeloid leukaemia. Courses subsequent to the first usually produce diminishingly good effects.

\section{Present Series}

These observations are based upon four patients with osteosclerosis, and five patients with myelosclerosis without demonstrable $x$-ray changes in the skeleton, who have been under my care. One patient with osteosclerosis is still living. Of the eight who have died, full post-mortem examinations were made upon seven. In the other case, one of advanced osteosclerosis that was under observation from 1923 to 1938 , only the spleen and liver were examined at necropsy.

Of these nine patients, seven had $x$-ray treatment, either to the spleen alone or to the spleen and long bones. One patient had severe anaemia when first seen; there was no increase in circulating leucocytes, though immature leucocytes, nucleated red cells, and megakaryocytes were present (the last up to $21 \%$ of the circulating leucocytes). Her response to blood transfusions was poor. Two injections of nitrogen mustard did no good, and she died four months after she was first seen. The remaining patient appeared as a case of acute leukaemia, with severe purpura, severe anaemia, slight leucopenia, immature leucocytes, and nucleated red cells in the circulating blood; he showed poor response to blood transfusions, and died two weeks after he was first seen and five months after the first symptoms of ill-health.

Of the seven patients who had $x$-ray treatment, two got no benefit. Neither of these had an increase in circulating leucocytes. One died of severe anaemia after five years' observation, during most of which time she had been able to work. Severe anaemia was present only during the last year. The other died of severe anaemia after 16 months' observation. Neither of these two patients responded well to blood transfusions; that is to say, this treatment improved the patient's health only slightly and temporarily.

But the remaining five patients got great benefit from $x$-ray treatment. They all had a large increase in circulating leucocytes, 20,000 to 70,000 per c.mm. before $x$-ray treatment. One, a patient with advanced osteosclerosis, was under observation from 1923 to 1938 , and died of heart failure, never having severe anaemia throughout. He had a short course of $x$-ray treatment to the spleen in 1936, which decreased the discomfort due to the large spleen. Another patient, with early osteosclerosis, is still living. He has been under observation from early 1949 until the time of writing. A course of $x$-ray treatment to the large spleen in July, 1952, greatly improved his feeling of well-being, relieved the severe abdominal symptoms, and stopped the cramp in the legs.

The remaining three patients had more than one course of treatment. One, a patient with advanced osteosclerosis, $x$-ray pictures of whose bones have been published (Hickling, 1937), had $x$-ray treatment in 1938, 1939, and 1941. The first two courses produced very good effects upon her general health and upon the abdominal symptoms. The last course produced much less effect, and she died of severe anaemia in 1942, after five and a half years' observation. Severe anaemia was present only during the last year of her life, and did not respond well to blood transfusions. A series of $x$-ray pictures of this patient's bones was made, and the degree of osteosclerosis appeared to diminish after the first course of $x$-ray treatment.

Another patient, with myelosclerosis, without $x$-ray changes in the bones, had three courses of $x$-ray treatment, in 1948, 1949, and 1950. This man's chief trouble was repeated severe gastro-intestinal haemorrhages. He died after four years and four months' observation. The first two courses of $x$-ray treatment improved his feeling of well-being and diminished the abdominal discomfort, but did not seem to diminish his tendency to gastro-intestinal haemorrhages.

The other patient had seven courses of $x$-ray treatment, to the first four of which his response was very good, though each course brought on an attack of gout, which started eight years before the first course of $x$-ray treatment. He died in 1945, of weakness, wasting, and chronic gout, after six and a half years' observation.

\section{Discussion}

A course of $x$-ray treatment should be planned so that just enough is given to relieve abdominal symptoms due to the large spleen. This also has the effect of relieving such general symptoms as tiredness, weakness, and cramps in the legs. If more than this is given, anaemia and leucopenia may occur. Two patients developed leucopenia as a result of too much $x$-ray treatment-one after the first and only course, and the other after the third course. In neither case did the leucopenia do any apparent harm. One patient developed anaemia after a course of $x$-ray treatment, which otherwise produced a good result, and slow recovery from the anaemia occurred.

Though many writers state that $x$-ray treatment of patients with myelosclerosis is harmful, some have reported good results (Reiche, 1927; Dameshek, 1945 ; Marson and Meynell, 1952 ; Nelson, 1952).

Most writers have taken the view that the myeloid metaplasia of the spleen and other organs is secondary to the fibrous or bony replacement of the bone marrow. Some believe that most cases of osteosclerosis or myelosclerosis are atypical forms of chronic granulocytic leukaemia (Custer, 1949). Others have suggested that myelosclerosis and osteosclerosis may be due to alterations in the undifferentiated cells of the bone marrow, of unknown origin, comparable to the alterations which cause increase in leucoblasts and erythroblasts (Vaughan and Harrison, 1939 ; Merskey, 1949 ; Moeschlin, 1951; Robson, 1952). The reduction in the degree of osteosclerosis of one of my patients under $x$-ray treatment supports this view, if it can be confirmed in other cases.

Splenectomy was not performed on any of the nine patients. Some authorities believe that occasionally this operation might do good (Bodley Scott, 1952 ; Richardson, 1952). References have been found to 14 patients with osteosclerosis or myelosclerosis who had splenectomy (Nauwerck and Moritz, 1905 ; Hirschfeld, 1914 ; Mettier and Rusk, 1937 ; Carpenter and Flory, 1941 ; Reich and Rumsey, 1942 ; Hittmair, 1944 ; Crail, 1946 ; Heller, Lewisohn, and Palin, 1947 ; Dustin, 1947 ; Crail, Alt, and Nadler, 1948 ; Wyatt and Sommers, 1950 ; Franks and Richardson, 1952). Of these 14 patients, four died within three months and four between ten months and six and a half years after splenectomy. Of the six recorded as having survived splenectomy, two survived a short time and four survived between one and five years. No striking improvement was produced in the condition of any of the patients, except one (Franks and Richardson, 1952). This patient was living several months after splenectomy and did not need the very frequent blood transfusions previously required.

\section{Case Reports}

Case 1.-A man aged 71. Presenting symptom, hardness of abdomen, and large spleen found February, 1949 . No anaemia, no polycythaemia. Leucocytes 26,000 per c.mm., $10 \%$ immature cells. Cramps in legs since 1947. General health good for his age. $X$-ray pictures of skeleton show early osteosclerosis, mainly of humeri. Sternal marrow active, all elements involved, many whole and fragmented megakaryocytes. $X$-ray treatment to spleen, July and August, 1952 ; spleen reduced in size, cramps in legs disappeared. Slight anaemia resulted, which gradually disappeared. In good health for his age, February, 1953.

Case 2.-A woman aged 65 died in December, 1951, of weakness, wasting, and heart failure, after five years' obser- 
vation. Presenting symptom, thrombosis of ventral vein of retina, December, 1946; enlarged spleen found. Slight anaemia, leucocytes 4,600 per c.mm., $19 \%$ immature cells. Spleen gradually increased in size, cramps in legs started in 1950, but she worked until April, 1951, when she became weak and ill. Sternal puncture failed to produce marrow cells. Trephine biopsy of sternum showed advanced myelosclerosis. No $x$-ray changes in boně́s. After April, 1951, blood transfusions, liver by mouth and by injection, cortisone and $x$-ray treatment to spleen were all ineffective. Necropsy: Intense myeloid metaplasia of spleen, Malpighian bodies little affected, many megakaryocytes ; slight myeloid metaplasia of liver; intense myeloid metaplasia of some lymph nodes; intense fibrosis of marrow of sternum, humerus, femur, ribs, and vertebral bodies.

Case 3.-A man aged 51 died of weakness and wasting, July, 1950, after four years and four months' observation. Presenting symptom, severe intestinal haemorrhage, March, 1946, when a large spleen was first found. These haemorrhages occurred at intervals from 1942 to 1949. Spleen gradually increased in size until 1948, when it reached beyond the midline. No polycythaemia. No anaemia, except after haemorrhages. Leucocytes 15,000 to 24,000 per c.m.m., immature cells 8 to $12 \%$, megakaryocytes 1.5 to $2.2 \%$. $X$ ray treatment December, 1948, caused shrinkage of spleen, decrease in total leucocytes, and percentage of immature cells. Second course in June and July, 1949, again produced improvement. Sternal marrow puncture produced a fluid poor in cells, in which megakaryocytic nuclei and other marrow cells can be seen. A third course of treatment in June, 1950, did no good. Necropsy: Intense fibrosis of marrow in sternum, humerus, and femur, but marrow cells recognizable among the fibrous tissue. Myeloid metaplasia of spleen, very few and small Malpighian bodies ; very slight myeloid metaplasia of liver; four ulcers, recent in origin, in jejunum.

Case 4.-A man aged 49 died of weakness, wasting, and anaemia in June, 1945, after six and a half years' observation. Presenting symptom, abdominal discomfort, and large spleen found, January, 1939. Attacks of gout since 1931. Cramps in legs since 1938. Bone $x$-ray pictures normal. No anaemia. Leucocytes 38,400 per c.mm., immature cells $13 \%$, nucleated red cells $3 \%$ of total nucleated cells in circulating blood. Sternal marrow active, May, 1943. $X$-ray treatment $1939,1940,1941,1942$. The first three courses produced very good results, the spleen shrinking, leucocytes diminishing, general health improving, and cramps in the legs disappearing. In 1943 weakness and wasting occurred, and anaemia, which did not respond well to blood transfusions. Necropsy: Fine fibrosis of marrow of sternum, ribs, and humerus, with spaces lined by endothelium packed with marrow cells, including large numbers of megakaryocytes. Myeloid metaplasia of spleen, with megakaryocytes; intense myeloid metaplasia of liver; few scattered areas of myeloid metaplasia in kidneys.

Case 5.-A woman aged 67 died of anaemia and heart failure in January, 1949, after five months' observation. Presenting symptoms, weakness and abdominal pains, September, 1948 ; anaemia and a large spleen found. Circulating leucocytes 8,000 per c.mm., of which $12 \%$ were immature cells ; $5 \%$ of nucleated cells were erythroblasts, and $4 \%$ megakaryocytes. Bone $x$-ray pictures normal. Sternal marrow puncture produced a fluid poor in cells, among which megakaryocytic nuclei were prominent. Poor response to blood transfusions. Megakaryocytes in circulating blood later rose to $21 \%$. Two injections of nitrogen mustard did not help. Necropsy: Dense fibrosis of marrow of humerus and sternum, no myeloid metaplasia of liver, intense myeloid metaplasia of spleen, megakaryocytes not conspicuous.

Case 6.-A man aged 71 died of weakness, wasting, and heart failure in March, 1938, after fifteen years' observation. Presenting symptom, abdominal pains, 1923, and large spleen found. No anaemia, no polycythaemia. Leucocytes 16,000 per c.mm. ; $31 \%$ immature cells, and $4 \%$ erythroblasts. No bone $x$-ray pictures until 1936, when extensive advanced osteosclerosis was found. Cramps in legs 1936 onwards. No treatment until 1936, when spleen extended nearly to the right anterior superior iliac spine. $X$-ray treatment caused some shrinkage of spleen. Leucocytes rose greatly at end, being between 40,000 and 90,000 per c.mm., from 1936 to 1938 , with monocytes 12 to $25 \%$. Necropsy: No other disease found, but only spleen and liver available for section. Intense myeloid metaplasia of spleen, mainly composed of one type of cell, Malpighian bodies absent; intense myeloid metaplasia of liver.

Case 7.-A woman aged 66 died of weakness, wasting, and anaemia in February, 1942, after six and a half years' observation. Presenting symptom, abdominal pains, 1935, and a mass felt in abdomen. At operation, performed on incorrect diagnosis, the mass was found to be a large spleen ; a spleniculus was removed for histology. Leucocytes 30,000 per c.mm., $18 \%$ immature cells. Cramps in legs 1939-42. Bone $x$-ray pictures, 1936, showed advanced osteosclerosis. $X$-ray treatment to spleen and long bones 1938, 1939, 1941. The first course produced excellent results, spleen shrinking, general health improving, and serial $x$-ray pictures of bones showed diminution in intensity of osteosclerosis, especially after the first course. The second course also did good, the last was ineffective. Necropsy: Dense osteosclerosis of sternum, humerus, femur, ribs. Intense myeloid metaplasia of spleen, no visible Malpighian bodies. The spleniculus removed in 1935 showed myeloid metaplasia of pulp, with unaffected Malpighian bodies. Moderate myeloid metaplasia of liver. Intense myeloid metaplasia of lymph nodes from different areas and of lymph tissue in appendix.

Case 8.-A man aged 61 died of wasting, weakness, and anaemia, November, 1940, after one year and four months' observation. Presenting symptoms, tiredness, and irritability of legs, but rarely cramps. Moderate anaemia, total leucocytes normal, constant presence of immature cells and erythroblasts. Bone $x$-ray pictures normal. Iron and liver extract by mouth were no help. $X$-ray treatment produced very slight improvement in his health, spleen shrank considerably. Later, blood transfusions produced transient improvement only. Necropsy: Fine fibrosis of marrow of sternum and humerus, with endothelium-lined spaces packed with marrow cells; megakaryocytes plentiful. Myeloid metaplasia of spleen ; Malpighian bodies not affected. Slight myeloid metaplasia of liver.

Case 9.-A man died of severe anaemia, June, 1952, after two weeks' observation. Presenting symptom, severe arthritis of hands, May, 1952. Moderate enlargement of spleen, purpura of legs and mucous membrane of mouth, severe anaemia, slight leucopenia, immature leucocytes $8 \%$, nucleated red cells $36 \%$. Serum uric acid $8.3 \mathrm{mg}$. per $100 \mathrm{ml}$. Sternal marrow puncture produced very few marrow cells. Poor response to large blood transfusion. Necropsy: Dense osteosclerosis of sternum and humerus, with practically no marrow cells visible ; myeloid metaplasia of liver, spleen, and spleniculus; Malpighian bodies present but small; megakaryocytes not conspicuous.

\section{Summary}

A brief account is given of the chief clinical features of patients who have sclerosis of the bone marrow.

Those patients who have large numbers of leucocytes in the circulating blood, with immature cells among them, respond well to $x$-ray treatment, regardless of the degree of marrow sclerosis.

Serial $x$-ray photographs of the bones of one patient, before. during. and after $x$-ray treatment, were taken by Dr. W. H Coldwell. Sir Alun Rowlands and Professor Clifford Wilson allowed me to see patients with myelosclerosis under their care. I am grateful to these gentlemen for their help.

\section{REFERENCES}

Assmann. H. (1907). Beitr. path. Anat., 41, 565

Carpenter, G., and Flory, C. M. (1941). Arch. intern. Med.. 67, 489 Collins. J. O., Sanger, R., Allen, F. H., and Race, R. R. (1950). British Medical Journal, 1, 1297

Crail. H. W. (1946). Arch. intern. Med., 78, 14. Alt. H. L., and Nadler, W. H. (1948). Blood. 3, 1426. 
Custer, R. P. (1949). An Atlas of the Blood and Bone Marrow, p. 81. Saunders, Philadelphia.

Dameshek, W. (1945). New Engl. J. Med., 232, 280.

Dustin, P. (1947). Acta clin. belg., 2, 212.

Franks, R. B., and Richardson, J. S. (1952). Proc. roy. Soc. Med., 45, 30

Heller, E. L., Lewisohn, M. G., and Palin, W. E. (1947). Amer. J. Path. 23, 327.

Heuck, G. (1879). Virchows Arch. path. Anat., 78, 475.

Hickling, R. A. (1937). Quart. J. Med., 6, 253.

Hirsch, E. F. (1935). Arch. Path., 19, 91.

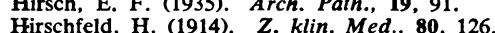

Hirschfeld, H. (1914). Z. klin. Med., 80,
Hittmair, A. (1944). Klin. Wschr., 23, 71.

Hutt, M. S. R., and Richardson, J. S. (1950). Proc. roy. Soc. Med., 43, 903.

Levinson, S. A., and Limarzi, L. R. (1947). Amer. J. clin. Path., 17, 449

Marson, F. G.. and Meynell, M. J. (1949). British Medical Journal, 2 , 1384.

(1952). Ibid., 1, 1113

Merskey, C. (1949). Arch. intern. Med., 84, 277.

Mettier, S. R., and Rusk, G. Y. (1937). Amer. J. Path., 13, 377.

Moeschlin, S. (1951). Spleen Puncture. Heinemann, London.

Mozer, J. J. (1927). Rev. méd. Suisse rom., 47, 802.

Nelson, M. G. (1952). Quart. J. Med., 21, 464.

Nauwerck, C., and Moritz, P. (1905). Dtsch. Arch. klin. Med., 84, 558

Paolino, W. (1949). Acta haemat., Basel, 2, 86.

Reich, C., and Rumsey, W. (1942). J. Amer. med. Ass., 118, 1200.

Reiche, F. (1927). Med. Klin., 23, 981.

Richardson, J. S. (1952), Ouart. J. Med., 21, 464

Robson, H. N. (1952). Ibid., 21, 464

Robson, H. N. (1952). Ibid., 21, 464.

. Med, 71, 793.

Scott, R. Bodley (1952). Quart. J. Med., 21, 464.

Sussman, M. L. (1947). Amer. J. Roentgenol., 57, 313

Vaughan, J. M., and Harrison, C. V. (1939). J.. Path. Bact., 48, 339

Windholz, F., and Foster, S. E. (1947). Stanford med. Bull., 5, 75

Wood, E. E., and Andrews, C. T. (1949). Lancet, 2, 739.

Wyatt, J. P., and Sommers, S. C. (1950), Blood, 5, 329.

\section{POLYCYTHAEMIA, LEUCO-ERYTHROBLASTOSIS, AND MYELOSCLEROSIS}

BY

\author{
J. W. BEATTIE, M.D., M.R.C.P. \\ Department of Clinical Medicine, University of Leeds \\ AND

\section{J. L. WITHEY, M.B., B.S. \\ Department of Pathology, Welsh National School of Medicine}

Reduction or obliteration of the bone marrow by connective-tissue proliferation or increased formation of bone occurs in the hereditary childhood condition of osteopetrosis, or marble bone disease of AlbersSchönberg, and also in a non-hereditary adult condition. This latter is probably best known as myelosclerosis, in which myelofibrosis or ossification of the marrow, sometimes called osteosclerosis, may be the predominant feature. The blood picture characteristically accompanying this condition shows leuco-erythroblastosis-defined by Vaughan (1936a) as " an anaemia characterized by the presence in the peripheral blood of unusually immature red cells and a few immature white cells of the myeloid series. The anaemia is not necessarily severe, nor is there usually a marked leucocytosis." Previous polycythaemia in cases which eventually showed leuco-erythroblastosis and myelosclerosis has been described by Lehndorff and Zak (1907), Hirsch (1935), Vogel, Erf, and Rosenthal (1937), Stone and Woodman (1938), Rosenthal and Bassen (1938), Markoff (1939), Vaughan and Harrison (1939), Thompson and Illyne (1940), Jackson, Lemon, and Parker (1940), Rosenthal and Erf (1943), Stealy and Sumerlin (1944), Windholz and Foster (1947), Marson and Meynell (1949), Merskey (1949), Wyatt and Sommers (1950), and H. N. Robson (personal communication, 1952).
We are here reporting three further cases presenting as polycythaemia and terminating as leuco-erythroblastic anaemia and myelosclerosis.

\section{Case 1}

A 69-year-old woman, first seen in May, 1946, complained of pain in the lumbar region and in the hips and calves for one year and an aching mass in the left side of the abdomen for five months. Examination revealed a malar flush with slight cyanosis, a moderately enlarged heart, splenomegaly extending down to the symphysis pubis and across to the right side of the abdomen, and slight hepatomegaly. A blood count showed: red cells, 5,920,000 per c.mm.; Hb, $113 \%$; white c:lls, 11,600 per c.mm. (premyelocytes $1 \%$, myelocytes $8 \%$, metamyelocytes $4 \%$, neutrophils $68 \%$, eosinophils $3 \%$, basophi's $2 \%$, lymphocytes $11 \%$, monocytes 3\%); 2 nucleated red cells per 100 white cells; and some polychromasia. Achlorhydria was present, serum calcium was $9.6 \mathrm{mg}$. per $100 \mathrm{ml}$., and the Wassermann reaction was negative.

Nearly four years later, in February, 1950, readmission was necessary for pain and weakness of the left leg, frequency and urgency of micturition, and weakness, lassitude, and loss of weight. Ankle oedema with pigmentation and ecchymoses over both legs was present. All other physical signs were unchanged. Liver-function tests and radiographs of the long bones were normal. A blood count showed: red cells, 3,100,000; $\mathrm{Hb}, 66 \%$; white cells 7,000 (myeloblasts $4.5 \%$, premyelocytes $0.5 \%$, myelocytes $6 \%$, metamyelocytes $0.5 \%$, neutrophils $56 \%$, eosinophils $0.5 \%$, basophils $5 \%$, lymphocytes $16.5 \%$, monocytes $8.5 \%$, atypical monocytes $1.5 \%$, mitotic figures $0.5 \%) ; 14$ nucleated red cells per 100 white cells ; and some macrocytosis. A biopsy of sternal marrow showed myelofibrosis; the haemopoietic tissue was almost entirely replaced by fibrous tissue; of the cellular elements megakaryocytes were present in increased numbers; polymorphonuclear cells with a small number of normoblasts could be seen scattered amongst the fibrous tissue; no haemosiderin could be detected by Perles's stain.

\section{Case 2}

A 48-year-old farmer's wife, when first seen in June, 1937, complained of morning hunger pains and three recent attacks of epigastric pain, backache, and vomiting. Examination showed a plethoric facies, slight sclerotic icterus, and splenomegaly extending $8 \mathrm{~cm}$. below the costal margin. A blood count showed: red cells $8,500,000 ; \mathrm{Hb}, 122 \%$; white cells, 9,100 (neutrophils $92 \%$, eosinophils $2.5 \%$, basophils $1.5 \%$, lymphocytes $2 \%$, monocytes $2 \%$ ) ; reticulocytes, $0.5-1 \%$; some macrocytosis and moderate anisocytosis. Bariummeal examination showed only displacement of the stomach to the right. The presumptive diagnosis being polycythaemia vera, the spleen was irradiated, with considerable improvement.

Irradiation of the humeri and femora with reduction in the blood count-which had again risen to red cells, $7,500,000 ; \mathrm{Hb}, 128 \%$; white cells, 7,400-was carried out in February and March 1942. She remained fairly well for over three years, apart from several severe epistaxes in January, 1944, and on July 19, 1945. In January, 1946, treatment was necessary for the anaemia, then present-red cells, $3,200,000$; Hb, $60 \%$; white cells, 3,000; subsequently her condition remained stationary for over three years. Further treatment for the anaemia was necessary in August, 1949. The blood count showed red cells, 2,500,000; Hb, $48 \%$; white cells, 4,200 (myelocytes $2 \%$, metamyelocytes $6 \%$, neutrophils $55 \%$, eosinophils $4 \%$, basophils $2 \%$, lymphocytes $29 \%$, monocytes $2 \%$ ); 12 nucleated red cells per 100 white cells; and $3 \%$ reticulocytes. The spleen extended almost into the left iliac fossa and the liver to $9 \mathrm{~cm}$. below the costal margin. Radiographs of the skull, pelvis, and long bones showed no abnormality. The redcell fragility test showed commencing haemolysis in $0.5 \%$ 